研究ノート

\title{
放電プラズマ焼結（SPS）法により作製したアルミナ焼結体中の気孔の形態とアルミナの還元挙動
}

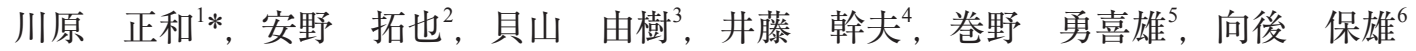 \\ ${ }^{1}$ 川原 SPS 技術事務所， $=238-0024$ 横須賀市大矢部 2-4-25. \\ 2 警察庁科学警察研究所, $=277-0882$ 千葉県柏市柏の葉 6 丁目 3-1. \\ ${ }^{3}$ いわき明星大学大学院， ₹ 970-8551 いわき市中央台飯野 5-5-1. \\ 4 大阪大学大学院工学研究科附属アトミックデザイン研究センター, † 565-0871 吹田市山田丘 2-1. \\ 5フォラムマッキー, † 612-8245 京都市西京区大原御陵 1-36 桂イノベーションパーク京都大学桂ベンチャープラザ北棟 S04. \\ ${ }^{6}$ 東京理科大学基礎工学部, ₹ 125-8585 葛飾区新宿 6-3-1.
}

\section{Pore Morphology and Reduction Behavior in Alumina Ceramics Fabricated by Spark Plasma Sintering (SPS)}

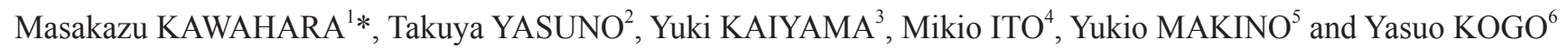 \\ ${ }^{1}$ Kawahara SPS Technical Office, 2-4-25 Yabe, Yokosuka 238-0024, Japan. \\ ${ }^{2}$ National Research Institute of Police Science, 6-3-1 Kashiwanoha, Kashiwa 277-0882, Japan. \\ ${ }^{3}$ Graduate Student, Iwaki Meisei University, 5-5-1 Iino, Chuoh-dai, Iwaki 970-8551 Japan. \\ ${ }^{4}$ Center for Atomic and Molecular Technologies, Graduate School of Engineering, Osaka University, 2-1 Yamadaoka, Suita 565-0871, Japan. \\ ${ }^{5}$ Forum MACKIY, North Bldg., S04, Kyoto Univ. Katsura Venture Plaza, Katsura Innovation Park, 1-36 Goryou Ohara, Nishikyou-ku, \\ Kyoto 612-8245, Japan. \\ ${ }^{6}$ Faculty of Industrial Science \& Technology, Tokyo University of Science, 6-3-1 Niijuku, Katsushika-ku, Tokyo 125-8585 Japan.
}

Received January 10, 2016; Revised February 23, 2016; Accepted March 3, 2016

\begin{abstract}
Alumina ceramics were fabricated by spark plasma sintering (SPS) at a temperature range between $1473 \mathrm{~K}$ and $1773 \mathrm{~K}$ from an ultrafine alumina powder of $120 \mathrm{~nm}$ in diameter. Microstructural observation and EDS analyses were carried out for the alumina sintered. When the alumina powder sintered at a temperature range between $1473 \mathrm{~K}$ and $1673 \mathrm{~K}$, the grain size of the peripheral parts in the alumina was larger than that of the central part in the alumina. The pore morphology in the peripheral parts of alumina was different from those in the central parts of alumina. The densification behavior of alumina powder during SPS changed according to the position in the alumina powder compact. From above results, the existence of temperature distribution in alumina powder compact during SPS consolidation was suggested. Chemical compositions in the vicinity of the pores on the triple grain boundary in the alumina sintered were different from the stoichiometric composition of alumina, indicating the possibility of reduction of alumina powder during SPS consolidation.
\end{abstract}

\section{KEY WORDS}

spark plasma sintering, grain growth, pore, alumina, reduction

\section{1 緒 言}

放電プラズマ焼結（SPS）法は, 成形が不要なことや昇温 速度制御の容易さなどから, 粉体の焼結体のみならず表面処 理, 合成, 接合体の成形など幅広い材料加工に適用されて おり ${ }^{1,2)}$, 切削工具 ${ }^{3,4)}$, 電子部品,6), バイオ ${ }^{7,8)}$, エネルギー関 連 ${ }^{9,10)}$ の材料創製など，様々な分野に応用されており，今後 さらなる展開が期待されている。 また, プロセス解析を含む

\footnotetext{
* Corresponding author, E-mail: kawahara@bk2.so-net.ne.jp
}

基礎的な研究も数多く試みられている。 しかしながら, 新規 材料の創製が先行し, 迅速な緻密化現象や通電効果など通電 下における焼結機構が十分に理解されていない。従来から指 摘されている粉末粒界における放電現象や局所的なジュール 熱の発生に関しても様々な議論がなされているが，現状では 定説が得られていない ${ }^{11,12)}$.

焼結体の組織から SPS 法の焼結現象を観察する試みは幾 つか認められる。例えば，SPS 法により作製された過共晶 Al-Si 合金の機械的性質に及ぼす微細組織の影響を検討した 
研究では，粉末粒子表面にある酸化膜の破壊と粒子表面にお ける局部融解による粒子間の良好な接合が SPS 焼結体に高 密度と高い引張強度を維持することが示されている ${ }^{13)}$.また, SPS とほぼ類似の焼結方法である PAS 法を用いたアルミナの 焼結では，ディスク状焼結体の中心部と周辺部では緻密化の 度合いが異なり，ビッカース硬度が焼結体の中心に向って低 下することが観察されている ${ }^{14)}$.さらに，アナターゼの SPS 焼結では, 加圧軸に垂直な平面内において結晶粒径が外周部 から中心部に向かって小さくなることが指摘されている ${ }^{15}$.

このような研究結果を考慮して, 本研究では高強度と透光 性を合わせ持つ機能性セラミックスの開発を目的として，代 表的なセラミックス材料であるアルミナ粉末を出発材料とし て選択し，SPS 法により成形されたアルミナ焼結体の組織を TEM 観察することにより，焼結体の緻密化に影響する気孔 の形態と気孔付近のアルミナの状態について新たな知見を得 たので報告する.

\section{2 実験方法}

出発材料としては, 平均粒子径 $120 \mathrm{~nm}$, 純度 $99.99 \%$ の $\alpha-\mathrm{A}_{2} \mathrm{O}_{3}$ （大明化学工業(株)製，TMDAR）を用いた。この粉 末 $12 \mathrm{~g}$ を外径 $50 \mathrm{~mm}$ 内径 $20 \mathrm{~mm} \times$ 高さ $40 \mathrm{~mm}$ の沉用型グラ ファイト製ダイに充填し, SPS 装置（SPS シンテックス製, Dr. Sinter SPS-520S）を用いて, 加圧力 $35 \mathrm{MPa}$ ，真空度約 $10 \mathrm{~Pa}$, 焼結温度 $1473 \sim 1773 \mathrm{~K}$, 昇温速度 $50 \mathrm{~K} / \mathrm{min}$ ，保持時 間 $5 \mathrm{~min}$ の条件で外径 $20 \mathrm{~mm} \times$ 厚さ $10 \mathrm{~mm}$ のディスクに成形 した．焼結温度としては，グラファイトダイの表面から中心 部に向かって, 予めドリル加工によって設けておいた，直径 $1.8 \mathrm{~mm}$ 深さ $5 \mathrm{~mm}$ の熱電対挿入用の穴の底の温度（ダイ内壁 から $10 \mathrm{~mm}$ の位置のダイ温度）を，放射温度計により測定 した值を用いた。なお，焼結中のダイからの輻射熱放出を抑 えるためにダイ外壁にはカーボンフェルトを巻いた。また， 成形した焼結体の抜型を容易にするために, ダイ内壁/パン チ外壁の間隙にはカーボンペーパーを挿入した。用いたグラ ファイト製ダイセットの形状と粉末の充墳図を Fig. 1 に示す.

TEM 観察用の試料作製は以下のように行った。まず, 種々 の温度で SPS 成形された $\phi 20 \mathrm{~mm}$ のディスク状焼結体の上 面, 中央面, 下面を厚さ $0.05 \mathrm{~mm}$ 以下まで切削・研削加工す
る. 次に, 得られた試料の中心部および周辺部を機械的に打 ち抜いて $\phi 3 \mathrm{~mm}$ 薄片状試料を得る。ささに, 高エネルギー イオン加工機を用いて加速電圧 $7.5 \sim 8 \mathrm{kV}$ ，イオン電流 15〜 $18 \mu \mathrm{A}$ ，ビーム照射時間 4 30 時間の条件で加工することに より薄膜状試料を得た。得られた薄膜状試料に対して, 透過 型電子顕微鏡（TEM：日本 FEI 製 TECNAI30S - Twin）を用 いて, 加速電圧 $300 \mathrm{kV}$ で明視野観察を行い, さらに, 付属 のエネルギー分散型 X 線分析装置 (EDS) を使用して元素分 析を行った.

\section{3 実験結果および考察}

\section{1 焼結体中央部および周辺部の微細組織}

焼結温度 $1473 \mathrm{~K} \sim 1773 \mathrm{~K}$ で成形したアルミナ焼結体の中 心部および周辺部から作製した試料の TEMによる組織観察 を行った。 得られた微細組織写真を Fig. 2 (a)〜(h)に示す.

Fig. 2 (a)に $1473 \mathrm{~K}$ で成形したアルミナ焼結体の中心部から 作製した試料の微細組織を示す．結晶粒は，原粉末の 2 倍か ら 4 倍の直径 $200 \mathrm{~nm} 500 \mathrm{~nm}$ まで成長しているが，気孔も多 数認められることから充分に緻密化していないことが分か る. Fig. 2 (b)に $1473 \mathrm{~K}$ で成形した焼結体の周辺部の微細組 織を示す。観察される気孔は僅かであり, 中心部と比較して 緻密化が進行していることが分かる。このことは，焼結温度 1473 K でディスク状のアルミナを SPS 成形する場合, 中心 部と周辺部では焼結速度に差があり, 中心部より周辺部の方 がやや早く緻密化すること示している.

$1573 \mathrm{~K}$ で成形したアルミナ焼結体の中心部と周辺部から 得られた組織を Fig. 2 (c) および (d) に示す。焼結体の中心部 に存在する気孔は僅かであるが, 周辺部では中心部と比べて やや多い数の気孔が散見される，また周辺部には，明らかに 粒界 3 重点に位置する気孔が認められる。結晶粒は $1473 \mathrm{~K}$ で成形した場合と比較すると成長しているが，中心部では平 均粒径 $600 \mathrm{~nm}$ 程度であり, 結晶粒成長はさほど顕著ではな い. しかしながら，周辺部では $1.5 \mu \mathrm{m}$ 程度まで成長してい る結晶粒もある。これらのことは, 焼結温度 $1573 \mathrm{~K}$ でディ スク状のアルミナをSPS 成形する場合, 周辺部の方が中心 部より粒成長が早いことを示している.

Fig. 2 (e) および(f)には，焼結温度 1673 K で成形したアル

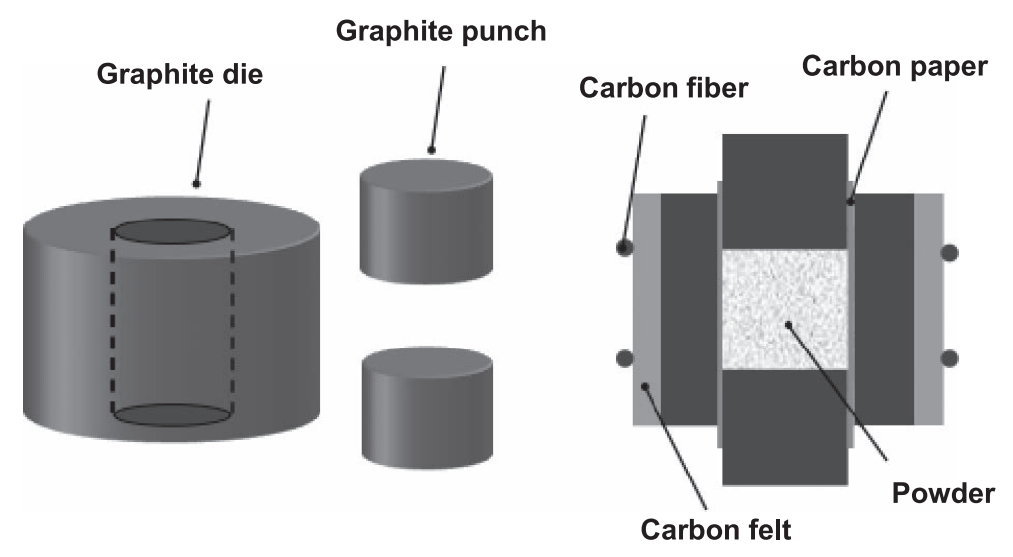

Fig. 1 Schematic illustration of the graphite die set used in the present study and the consolidation of alumina powder using the die set. 


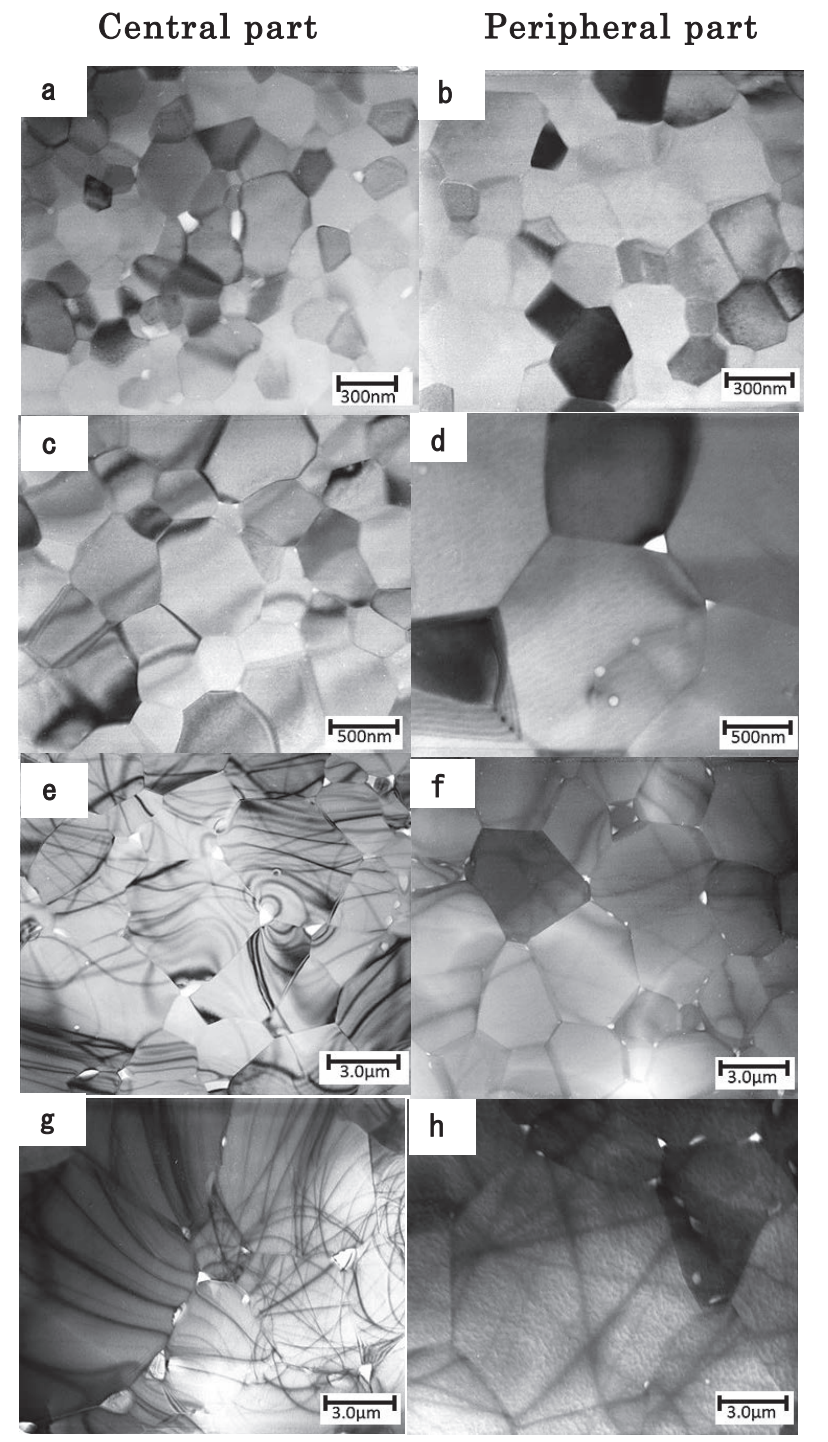

Fig. 2 Transmission electron micrographs taken from peripheral and central parts of alumina fabricated at various sintering temperatures by SPS. (a) and (b) sintered at $1473 \mathrm{~K}$, (c) and (d) sintered at $1573 \mathrm{~K}$, (e) and (f) sintered at $1673 \mathrm{~K}$ and (g) and (h) sintered at $1773 \mathrm{~K}$.

ミナ焼結体の中心部および周辺部から作製した試料の微細組 織を示す. 粒界 3 重点に多数の気孔が確認され, 結晶粒径も 大きい粒では $5 \mu \mathrm{m}$ 以上のものが認められる。焼結体の中心 部および周辺部のいずれにおいても顕著な粒成長が認められ る. 中心部の結晶粒径と比較して周辺部のそれは若干大きく なっているが, $1573 \mathrm{~K}$ 以下で成形した場合と比較してその 差は小さくなってきている.このことは低温ではやや遅延気 味の中心部における粒成長が $1673 \mathrm{~K}$ で周辺部の粒成長に追 い付いてきたものと考えられる。 また，中心部および周辺部 を比較すると, 粒界 3 重点に認められる気孔の数はそれほど 変わりないが, 気孔径は中心部が粗大化している.

Fig. 2 (g) および (h) は焼結温度 $1773 \mathrm{~K}$ で成形したアルミナ 焼結体の中心部および周辺部から得られた試料微細組織であ る。焼結体の中心部および周辺部のいずれにおいても多くの 気孔が粒界 3 重点に観察され，また，2粒界間にも気孔が確 認される．結晶粒径は焼結体の中心部および周辺部のいずれ

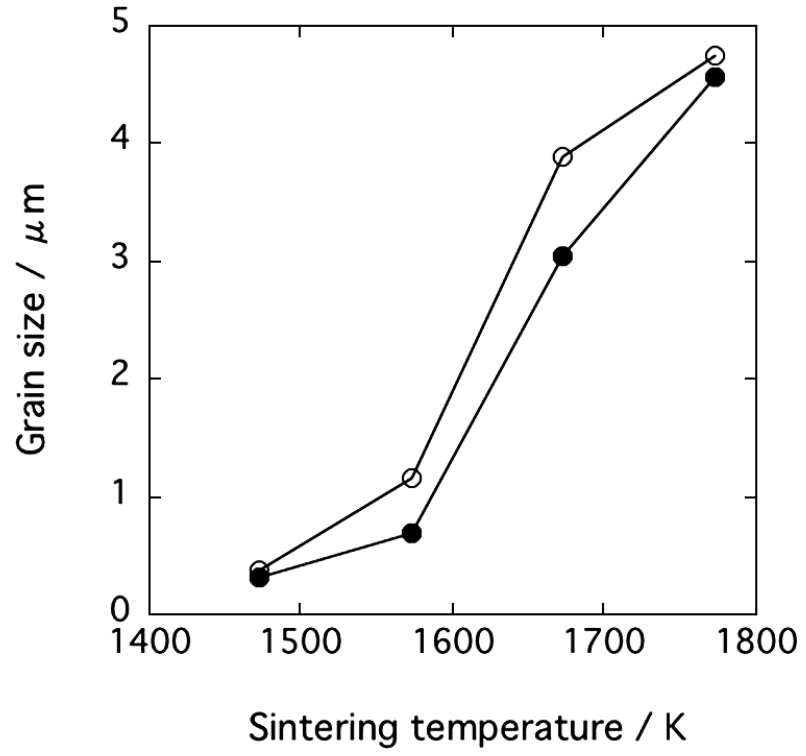

Fig. 3 Change in the crystal grain size of central and peripheral part in alumina fabricated by SPS as a function of the sintering temperature. Dark circles for central parts and open circles $\bigcirc$ for peripheral parts.

においても著しく粗大化し, 粒によっては $6 \mu \mathrm{m}$ 以上も粒成 長していることが示される.

以上の各温度で成形されたアルミナ焼結体の微細組織観察 結果は, 絶縁性材料であるアルミナ粉末を導電性を有するグ ラファイト製ダイでディスク形状に SPS 成形する場合, 少 なくとも焼結温度 $1673 \mathrm{~K}$ 以下では，成形中にディスクの半 径方向に温度分布が生じていることを示唆している．すなわ ち, 中心から周辺部に向かうにしたがってやや高温になると いう温度勾配が生じているものと思われる。

3.2 焼結体中央部および周辺部の結晶粒径の焼結温度依存性

焼結体中央部および周辺部における TEM 像から各焼結温 度の平均結晶粒径を求め, 結晶粒径の焼結温度依存性を検

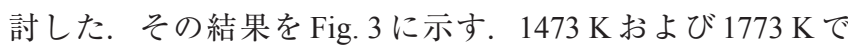
SPS 成形した場合, 中心部と周辺部の平均結晶粒径に大きな 差は認められないが, 中間の $1573 \mathrm{~K}$ および $1673 \mathrm{~K}$ で成形し た場合, 中央部の平均結晶粒径と比較して周辺部の結晶粒径 の平均值が $0.5 \mu \mathrm{m} \sim 1.0 \mu \mathrm{m}$ 大きくなっている. この結果は中 間温度領域（1573 K 1673 K ）において周辺部と中央部にお ける焼結性の相違が生じることを示している，その原因は中 間温度領域では試料中央部と周辺部で生じる温度差によると 考えられる.このような結果はアナターゼ固化体の作製にお いても指摘されている ${ }^{14)}$. SPS 法による焼結では, 試料中央 部と周辺部で生じる温度差は, 焼結体の大きさや形状のみな らず焼結される粉体の電気的特性や SPS 焼結のプロセス条 件に依存するので，大型部材の作製のみならず厳格な均質性 が要求される先進機能材料の創製にも重要な因子となる.

3.3 焼結体中央面の $\mathrm{Al}$ および酸素 $(\mathrm{O})$ 濃度

各温度でSPS 成形したアルミナ焼結体内部の元素分布を 明らかにするためにエネルギー分散 X線分析法により元素 分析を行った. Fig. 4 に各焼結温度で成形した試料中の粒界 


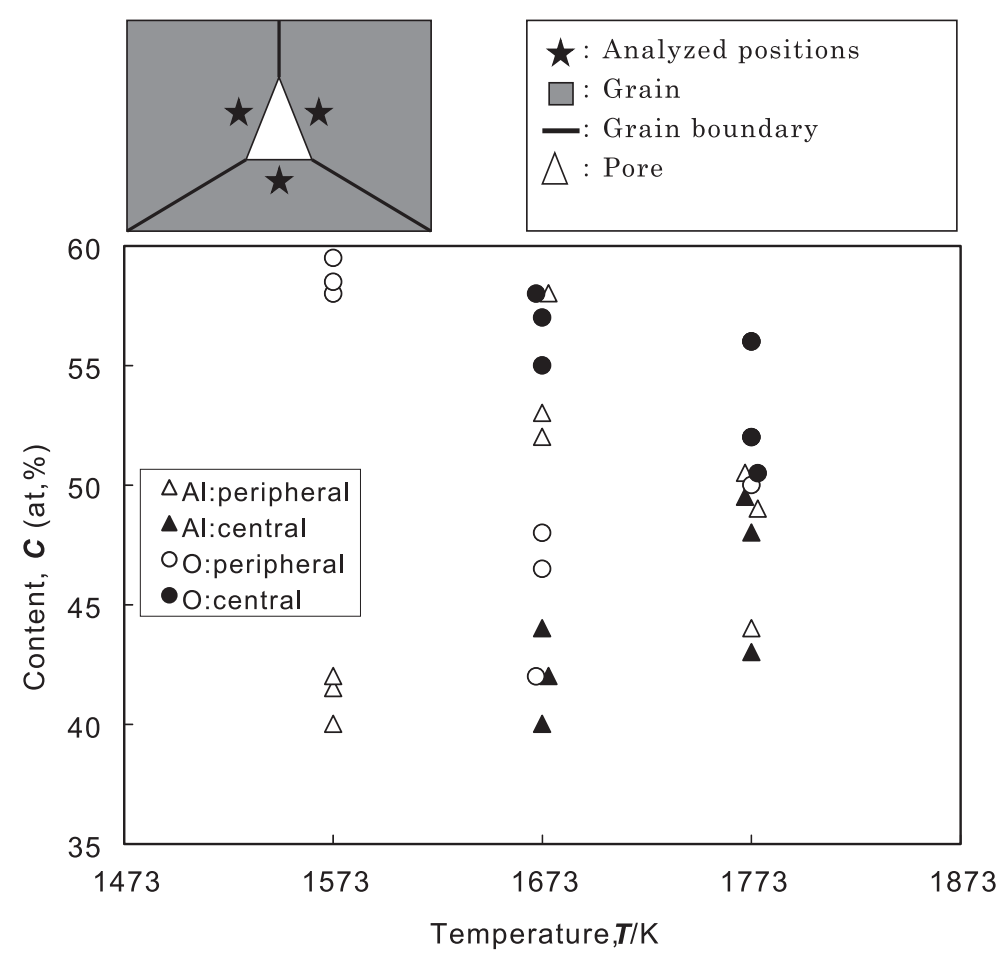

Fig. 4 Aluminum (Al) and oxygen (O) content in alumina fabricated at various sintering temperatures by SPS. Open and dark triangles, $\triangle$ and $\boldsymbol{\Delta}$ for Al contents in the positions near the pores located at the triple points in peripheral and central parts, respectively. Open and dark circles, $\bigcirc$ and $\bigcirc$ for oxygen contents in the positions near the pores located at the triple points in peripheral and central parts, respectively.

3 重点に位置する気孔近傍を 3 点ずつ分析して得られた $\mathrm{Al}$ お よびOの分析值 (at \%) を示した.

焼結温度 1573 K で成形したアルミナ燒結体周辺部の試料 中の粒界3 重点に位置する気孔近傍の $\mathrm{Al}$ 及び $\mathrm{O}$ 濃度は，そ れぞれ，概ね 40 42 at $\%$ および 58 60 at $\%$ となり，化学量論 值よりも低い $\mathrm{O}$ 量が検出されている.

焼結温度 $1673 \mathrm{~K}$ で成形した焼結体の中心部の試料中の粒 界 3 重点に位置する気孔近傍の $\mathrm{Al}$ 及び $\mathrm{O}$ 濃度は, 焼結温度 $1573 \mathrm{~K}$ で作製した試料焼結体の周辺部の試料から得られた $\mathrm{Al}$ および $\mathrm{O}$ 濃度と $2 \%$ 程度の差は認められるもののほぼ同 濃度を示す。しかしながら，1673 K で作製した焼結体の周 辺部の試料中の粒界 3 重点に位置する気孔近傍では, $\mathrm{Al}$ 濃 度は 50 60 at \% で，逆に O 濃度は $42 \sim 48 \mathrm{at} \%$ となり, $\mathrm{Al}$ と $\mathrm{O}$ の比率は化学量論比 $(\mathrm{Al} / \mathrm{O}=2 / 3)$ よりも著しく小さい值 が得られている。

さらに焼結温度 $1773 \mathrm{~K} て ゙$ 作製した焼結体の中心部拉よび 周辺部から得られた試料中の 3 重点に位置する気孔近傍で は，中心部打よび周辺部ともバラッキはあるものの, $\mathrm{Al}$ 濃 度は 43〜 50 at \% で，O濃度は 50 57 at \%となり，化学量論 比の場合に比較して低い $\mathrm{O}$ 濃度であることが指摘される。

これらの全ての分析結果から $\mathrm{Al}$ 濃度は, $1673 \mathrm{~K}$ で作製した 焼結体の周辺部の試料を除いて，40～ $50 \mathrm{at} \% ， \mathrm{O}$ 濃度は 50〜 $60 \mathrm{at} \%$ となり, 化学量論比の場合に比較して低い $\mathrm{O}$ 濃度で あると結論される。 また，全ての試料の全ての分析点で $\mathrm{O}$ 濃度は化学量論比の場合と比較して低くなっていると結論さ れる.アルミナ中の $\mathrm{O}$ 濃度が化学量論比の場合 $(66.7 \mathrm{at} \%)$ よりも低くなっている原因として（1）試料作製中でのアル
ミナの還元，(2) 焼結中でのアルミナの還元, が考えられる.

（1）の場合には，電子顕微鏡観察用の試料作製の際，イ才 ンビームによって薄膜化しているので，イオンビームによる Oイオンの選択的弾き出しによってアルミナが還元状態にな ることが考えられる。しかしながら，この場合加速電圧が $7.5 \mathrm{kV} \sim 8 \mathrm{kV}$ であるので，スパッタリング効果を考えれば 良い.アルミナの場合は数 $\mathrm{kV}$ のスパッタリングでは原子配 列が乱されるのみで還元は認められていない ${ }^{16,17)}$. したがっ て, 試料作製する時のイオンビーム加工による還元とは考え 難い．（2）のSPS 焼結中にアルミナが還元される可能性を 考えると, 通常の還元プロセスでは水素や $\mathrm{CO}$ のみによって アルミナが還元されることは考えられない。しかしながら， 通電効果が還元に対して付加的な効果を引き起こしているこ とは考えられる。例えば以下のように，スパークプラズマに よってアルミナが気化, 分解し, その結果生ずる $\mathrm{Al}_{2} \mathrm{O}$ ガス がアルミナ表面に吸着し，アルミナと反応する結果としてポ ア表面及び近傍のアルミナの組成が変化する機構を考えると 気孔発生と気孔付近の $\mathrm{O}$ 量の低減は説明可能である。還元 のメカニズムとして通電による粒表面電流に関係する随伴還 元効果とスパークプラズマによる一部アルミナの分解・蒸着

$$
\left(\mathrm{Al}_{2} \mathrm{O}_{3} \rightarrow \mathrm{Al}_{2} \mathrm{O}(\mathrm{v})+\mathrm{O}_{2}(\mathrm{v}), \quad \mathrm{Al}_{2} \mathrm{O}_{3}+\mathrm{xAl}_{2} \mathrm{O}(\mathrm{v}) \rightarrow \mathrm{Al}_{2} \mathrm{O}_{3-\mathrm{y}}\right)
$$

が示唆されるが，SPS 焼結した酸化物セラミックスにおいて 確証は得られていない，別の解釈として，緻密化までの間に 粒表面で $10^{6} \sim 10^{7} \mathrm{~V} / \mathrm{cm}$ の電場下で選択的に電流が流れること による ${ }^{18)}$ 酸素原子の弾き出し効果も可能性がある。焼結温度 が高くなると共に，アルミナ焼結体の密度が微減する現象が 
認められることも関係があると思われる.

確証を得る研究が今後求められる. 別の解釈として緻密化 までの間に粒表面に選択的に電流が流れることに $\mathrm{O}$ 原子の 弾き出し効果も可能性がある。焼結温度が高くなると共に,

アルミナ焼結体の密度が微減する現象が認められることも関 係があると思われる。

3.4 焼結体上面および下面の微細組織

焼結温度 $1773 \mathrm{~K}$ で SPS 成形した焼結体の上面および下面 の中心部と周辺部の TEM 観察によって得られた微細組織を Fig. 5 に示す。焼結体の上面の中心部には気孔が粒界 3 重点, 2 粒界および粒内に存在していることが認められる。気孔の
大きさは様々であるが，最大で $400 \mathrm{~nm}$ 程度である． 3 重点 に位置する気孔が多く，2 粒界に存在する気孔や粒内に存在 する気孔はそれ程多くないことが認められる。

焼結体の上面の周辺部には，中心部と比較して気孔数は明 らかに増加しており，粒内に存在する気孔も非常に多く観察 される，気孔の大きさは様々であるが，最大で $500 \mathrm{~nm}$ を越 えるものは認められない. また，粒内に認められる気孔の形 状は楕円状のものが多く, 長軸の方向が一方向に揃っている ように観察される，楕円状気孔の長軸方向が揃うことは粒の 成長方向，あるいは質量拡散の方向が一方向であることを示 唆している可能性がある.

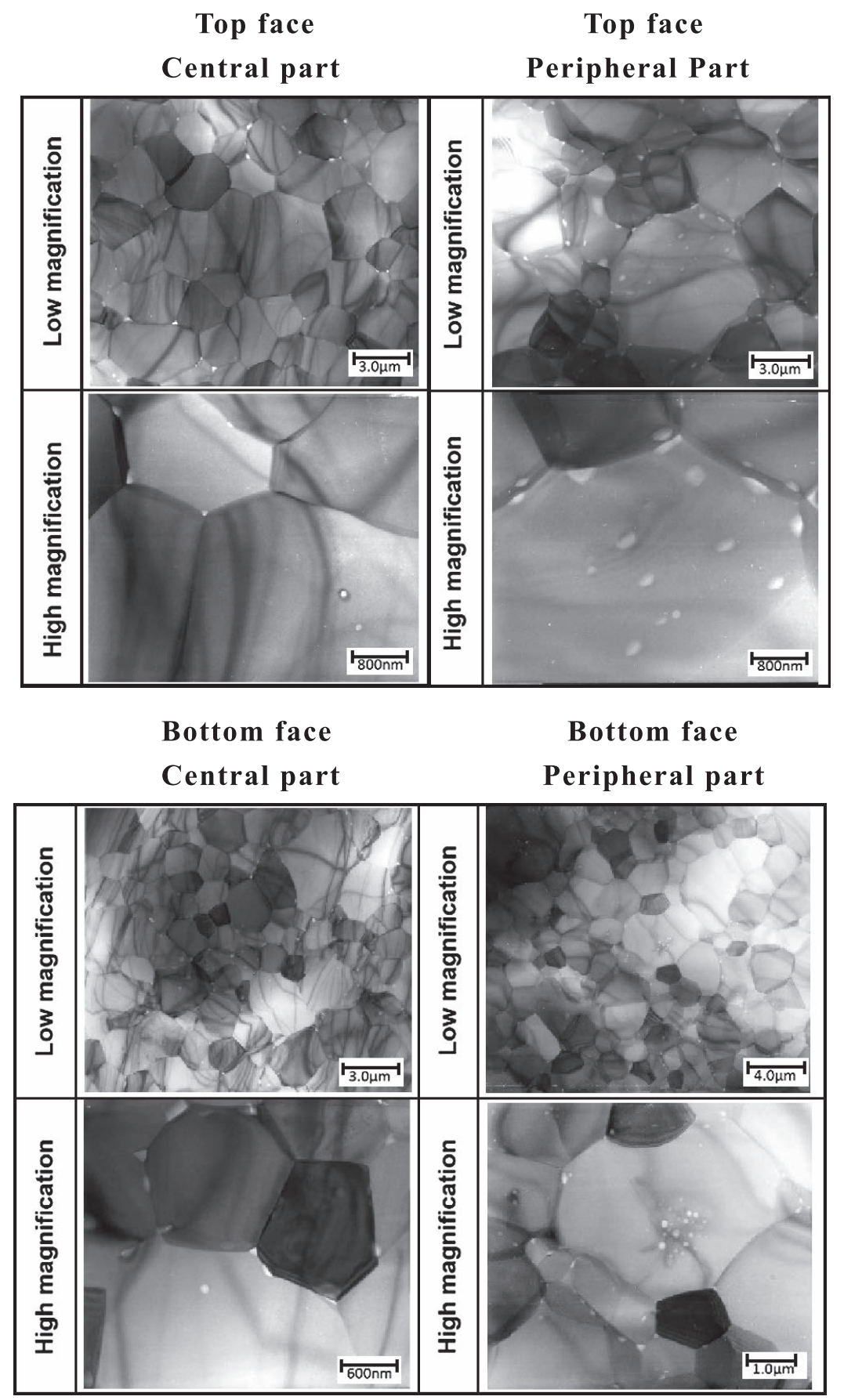

Fig. 5 Transmission electron micrographs taken from various parts of alumina fabricated at $1773 \mathrm{~K}$ by SPS. 
Table 1 Grain sizes on various positions in alumina sintered at $1773 \mathrm{~K}$ by SPS.

\begin{tabular}{lccccc}
\hline \multirow{2}{*}{ Area } & \multicolumn{2}{c}{ Top face } & & \multicolumn{2}{c}{ Bottom face } \\
\cline { 2 - 3 } \cline { 5 - 6 } & Central & Peripheral & & Central & Peripheral \\
\hline Grain size, $\boldsymbol{d} / \mu \mathrm{m}$ & 3.25 & 3.3 & & 2.6 & 2.8 \\
\hline
\end{tabular}

一方，焼結体の下面の中心部から得られた微細組織を上面 の中心部と比較すると，気孔数はそれほど変わらないが, 歪 みによる干渉コントラストが数多く観察される.

さらに，焼結体の下面の周辺部の微細組織を上面の周辺部 と比較すると, 気孔数も気孔が存在する箇所も著しく異な り，粒内の特定な個所に集中しているように観察される。下 面の周辺部の気孔数や気孔の存在状態は, 上面の中心部, 下 面の中心部とほとんど変わらない.

上面の中心部，上面の周辺部，下面の中心部および下面の 周辺部の 4 箇所を比較すると, 上面の周辺部においてのみ気 孔数が多く，粒内に存在する気孔も数多く認められる. また 上述したように，下面の中心部においてのみ歪みによる干渉 コントラストが数多く観察される. 以上の結果は, 絶縁性材 料であるアルミナ粉末を導電性を有するグラファイト製ダイ でディスク形状に焼結温度 $1773 \mathrm{~K}$ で SPS 成形する場合, 成 形中にディスクの半径方向のみならず厚さ方向にも温度分布 が生じていることを示唆しているが, このことについては, さらに詳細な検討が必要である。

3.5 焼結温度 $1773 \mathrm{~K}$ で SPS 成形されたアルミナ焼結体の平 均結晶粒径

焼結温度 $1773 \mathrm{~K}$ で SPS 成形されたアルミナ焼結体の TEM 観察により得られた微細組織写真から算出した平均結晶粒径 を Table 1 に示す．焼結体下面より上面の粒径の方が粗大で あることが確認できる。また，これまでの実験結果でも明ら かであるように，焼結体中心部より周辺部の粒径のほうがや や粗大であることが明らかにされている．結晶粒が粗大化す ることは, SPS 法による焼結では焼結温度が高いことに対応 する.すなち, 上部パンチと接触する焼結体の上面の温度が 中心部の測定温度よりも高いと結論される。この結論はアル ミナに対する複雑形状圧粉体系の電気-熱連成解析に基づい たシミュレーションの結果と良い一致を示す ${ }^{19,20)}$. 上面の周 辺部においてのみ気孔数が多く観察されたことも上面の周辺 部で高温となることに関連すると考えられる.

\section{4 結 論}

アルミナ粉末を放電プラズマ焼結法により種々の条件で成 形し, 得られたアルミナ焼結体の中心部および周辺部に対し て，TEM 観察および EDS 分析を行うことにより以下のこと が明らかとなった。

(1) TEMによる微細組織観察から焼結体中心部と比較して 周辺部において結晶粒の粗大化が観察された。この結果 より, 少なくとも焼結温度 $1473 \mathrm{~K} \sim 1673 \mathrm{~K}$ の範囲では, 周辺部が中心部よりも高温になっていることが示唆される.
（2）焼結体中に残存する気孔の数や形態は，焼結温度により 変化するのみならず, 焼結体の中心部と周辺部でも異なる.

(3) EDS 分析結果により, 焼結体中心部・周辺部ともに粒界 3 重点における気孔周辺の酸素量の低減が認められた. その理由として粒表面のアルミナの還元によると考えら れる．還元のメカニズムとして通電による粒表面電流に 関係する随伴還元効果とスパークプラズマによる一部ア ルミナの分解・蒸着 $\left(\mathrm{Al}_{2} \mathrm{O}_{3} \rightarrow \mathrm{Al}_{2} \mathrm{O}(\mathrm{v})+\mathrm{O}_{2}(\mathrm{v}), \mathrm{Al}_{2} \mathrm{O}_{3}+\right.$ $\left.\mathrm{xAl}_{2} \mathrm{O}(\mathrm{v}) \rightarrow \mathrm{Al}_{2} \mathrm{O}_{3-\mathrm{y}}\right)$ が示唆されるが, 確証を得る研究が 今後求められる.

（4）上部パンチと接触する焼結体上面部の結晶粒粗大化によ り焼結体の上面の温度が中心部の測定温度よりも高いこ とが明らかとなった。この結果は複雑形状圧粉体系の電 気一熱連成解析に基づいたシミュレーションの結果と良 い一致を示す。

\section{文献}

1) "Parusutsuudenba Puroseshingu Sousetsusyuu", Ed.-in Chief by Y. Makino, TIC, (2010) 131-340.

2) M. Tokita: "Development of hardware and software for spark plasma sintering", J. High Temperature Soc., 31 (2005) 215224.

3) J. Zhao, T. Holland, C. Unuvar, Z. A. Munir: "Spark plasma sintering of nanometeric tungsten carbide", Int. J. Refractory Metals \& Hard Materials, 27 (2009) 130-139.

4) Y. Zheng, S. Wang, Y. Yan, N. Zhao, X. Chen: "Microstructure evolution and phase transformation during spark plasma sintering of Ti(C,N)-based cermets", Int. J. Refractory Metals \& Hard Materials, 26 (2008) 306-311.

5) R. Mazumder, D. Chakravarty, D. Bhattacharya, A. Sen: "Spark plasma sintering of $\mathrm{BiFeO}_{3}$ ", Mater. Res. Bulletin, 44 (2009) 555-559.

6) N. Ichinose: "Preparation of Electronic Materials by spark plasma sintering", Mater. Sci. and Technol., 40 (2003) 154159.

7) W. Que, K. A. Khor, J. L. Xu, L. G. Yu: "Hydroxyapatite/ titania nanocomposites derived by combining high-energy ball milling with spark plasma sintering processes", J. Euro. Ceram. Soc., 28 (2008) 3083-3090.

8) X. Wan, A. Hu, M. Li, C. Chang, D. Mao: "Performance of $\mathrm{CaSiO}_{3}$ ceramic sintered by spark plasma sintering”, Materials Characterization, 59 (2008) 256-260.

9) K. Biswas, J. He, I. D. Blum, C. -I. Wu, T. P. Hogan, D. N. Seidman, V. P. Gravid, M. G. Kanatzidis: "High-performance bulk thermoelectrics with all-scale hierarchical architectures", Nature, Vol. 489 (2012) 414-418.

10) W. Liu, X. Yan, G. Chen, Z. Ren: "Recent advances in thermoelectric nanocomposites", Nano Energy, 1 (2012) 42-56.

11) Y. Makino: "Synthesis of nano-Structured materials with pulsed high current heating”, J. High Temp. Soc. Jpn., 31 (2005) $202-$ 
208.

12) D. M. Hulbert, A. Anders, J. Andersson, E. J. Lavernia, A. K. Mukherjee: "A discussion on the absence of plasma in spark plasma sintering”, Scripta Materialia, 60 (2009) 835-838.

13) T. Yasuno, T. Naruse, T. Khono, M. Kawahara, M. Tokita; "Effects of Microstructure on Mechanical Properties of Hyper Eutectic Al-Si Alloy Produced by Spark Plasma Sintering”, J. Jpn. Soc. Powder Powder Metallurgy, 56 (2009) 758-762.

14) S. W. Wang, L. D. Chen, T. Hirai, Y. S. Kang: "Microstructure inhomogeneity in $\mathrm{Al}_{2} \mathrm{O}_{3}$ sintered bodies formed during the plasma-activated sintering process”, J. Mater. Sci. Letts, 18 (1999) 1119-1121.

15) Y. Makino, T. Nakanishi, H. Saito: "Estimation of Homogeneity in Pulsed High Current Sintering by Crystallographic Character of Consolidated Anatase", J. Jpn. Soc. Powder Powder Metallurgy, 53 (2006) 909-914.
16) H. J. Mathieu: "Thin Film and Depth Profile Analysis", Chap.3, ed. by H. Oechsner, Springer-Verlag, (1984).

17) K. S. Kim, W. E. Baitinger, J. W. Amy, N. Winograd: "ESCA studies of metal-oxygen surfaces using argon and oxygen ionbombaedment", J. Electron Spectrosc. \& Relat. Phenom., 5 (1974) 351-367.

18) R. Chaim: "Densification mechanism in spark plasma sintering of nanocrystalline ceramics", Mater. Sci. Eng. A443 (2007) 25-32.

19) K. Matsugi, G. Sasaki, O. Yanagisawa: "Thermal Analysis of Spark Sintering with Molds in Different Shapes and Different Powders", J. Jpn. Soc. Powder Powder Metallurgy, 50 (2003) 238-247.

20) K. Matsugi, O. Yanagizawa, G. Sasaki: “Analysis and Control in Spark Sintering Process and Its Micro-Macro Modeling", J. Jpn. Soc. Powder Powder Metallurgy, 56 (2009) 355-370. 